\title{
Scientific-Based Guided Inquiry Learning Model in Learning Chemistry in Class XI IPA Students of SMAN 1 Rote Timur

\section{| Cartika Candra Ledoh ${ }^{1, *}$ | Sentot Budi Raharjo² | Sulistyo Saputro ${ }^{3}$ |}

${ }^{1}$ Master of Chemistry Education, Postgraduate School, Universitas Sebelas Maret, Indonesia

${ }^{2,3}$ Department of Chemistry Education, Faculty of Teacher Training and Education, Universitas Sebelas Maret, Indonesia

*cartikacandraledoh1@gmail.com

\begin{abstract}
The purpose of this study is to determine the cognitive and effective learning outcomes of chemistry students using a scientifically based guided inquiry learning model. This study employed a quantitative methodology.. The population in this study consisted of 58 students from class XI at State Senior High School 1 Rote Timur, NTT For the 2019/2020 academic yea. Cluster random sampling was used to select the sample, which included two experimental and control classes. Tests, questionnaires, and observation sheets were used to collect data. The independent test samples t-test was used to analyze student learning outcomes. The finding showed that learning outcomes using the ScientificBased Guided Inquiry Model and the direct method differs significantly from average high school learning outcomes. The results of the two aspects of learning outcomes, namely aspects of knowledge, and attitudes show a value of $p<0.05$ so that $\mathrm{HO}$ is rejected and $\mathrm{Ha}$ is accepted. Thus, there are differences in student learning outcomes given the learning method using guided inquiry with students using conventional learning. However, from the results of data analysis, it was obtained that the p-value for the knowledge aspect was 0.000 , the pvalue for the attitude aspect was 0.038 .
\end{abstract}

KEYWORDS

guided inquiry; scientific; chemistry teaching

\section{INTRODUCTION}

21st century learning demands a change from conventional teacher-centered into studentcentered. In this case, teacher has a very important role to change learning patterns. In this case, learning is an effort made by teachers deliberately to convey knowledge, organize and create a learning environment with the help of various methods, so that students can carry out learning activities effectively and efficiently to get maximum results (Uzuntiryaki 2010). .

According to the Curriculum of 2013, learning activity must be student-centered. However, the implementation of the Curriculum of 2013 has not been fully implemented according to its objectives. Many teachers in schools apply the lecturing method with question and answer sessions. The lecture method keeps students from being passive in learning. In addition, the lecturing method makes students less understanding in the learning process.

Based on the results of observations and interviews at State Senior High School of 1 East Rote, East Nusa Tenggara in the odd semester of 2019/2020 academic year, the learning process is still ineffective because students do not understand the teacher's explanation. As a result, students tend to be passive and have low learning outcomes. In the learning process 
the teacher often uses the lecturing method that places students as note takers and loyal listeners. This results in students having limited abilities in learning. The weakness of the lecturing method itself is that students only master the material provided by the teacher, but the teacher has difficulty in ascertaining whether the students understand or not the material taught (Sanjaya 2006)

In addition, if the teacher has poor speaking skills, the lecturing method will be boring and students' interest in learning will decrease. Based on the description above, students get a minimum portion of knowledge from the teacher because of the method used. This is reinforced by the results of daily test results of the reaction rate material in the previous academic year, 2019/2020, with an average score of 67 where it is is below the minimum completeness standard (KKM). Moreover, there is no appropriate learning media used. According to the problem, innovation is needed in implementing a learning model that is in accordance with the objectives of the Curriculum of 2013. In addition, the learning model must in accordance with the characteristics of students and their teachers. Guided inquiry is suitable in Chemistry teaching.

Guided inquiry learning model is a learning model which in practice requires the active engagement of students with the teacher's guidance in solving a problem Kuhlthau In this model, teachers should have the skills to provide guidance that diagnose student difficulties and provide assistance in solving the problem (Oemar, 2001) The guided inquiry learning model also deals with many elements of divergent thinking, such as creative thinking and convergent thinking. Problem solving requires students to explore and examine critically a problem and involves the ability to think critically, identify problems and use various skills in synthesizing and solving problems.

Its main objective is to develop students' attitudes and skills to solve problems independently (Ngalimun 2017 \& Coffman 2009). In addition, in order to make students actively involved in the learning process, it does not only require an appropriate learning model but an appropriate learning approach also needs to be applied (Kuhlthau 2007) .The learning approach that is in accordance with the Curriculum of 2013 in the Guided Inquiry learning model is Scientific Approach.

A scientific approach is an approach that adopts scientific steps in building knowledge through the scientific method. According to Alfred De Vito (Machin 2014) .The scientific approach includes activities to notice (observing), ask (questioning), reason (associating), try (experimenting), and form networks (networking) for all subjects. Learning models that are in accordance with the scientific approach are discovery, inquiry, problem based learning, and project based learning (Kemendikbud, 2013)

The scientific approach develops the scientific thinking skills, development of a "sense of inquiry" and critical thinking skills. This idea is in line with the opinion of the Minister of Education and Culture (2013) who said that the scientific approach is a learning process designed in such a way that students actively compile concepts, laws, or principles through identifying and formulating stages. problems, propose or formulate hypotheses, collect data by various techniques, analyze data, draw conclusions and communicate concepts, laws, or principles.

The results of research conducted by (Conway 2014, Anderson 2010) shows that the learning process that applies the guided inquiry learning model is effective in improving learning outcomes compared to learning without guided inquiry. This is because students make direct observations of objects as scientists do.

In addition, a study conducted by (Machin, 2014) states that the application of this approach has a positive effect on cognitive, affective, and psychomotor learning and it also achieves the determined classical completeness, namely more than $85 \%$ of the whole students who 
involve in the learning process. This is because students make direct observations of the objects as the scientists do.Constructivist learning is a theory of learning that guides the practice of learning for many teachers (Uzuntiryaki 2010). The characteristics of constructivist learning, which change the learning paradigm from the focus of teachercentered to student-centered include innovative learning models that teachers can use to assist them in planning and carrying out learning activities in the classroom to achieve learning goals.

Based on the description above, the author is interested in conducting research entitled "Guided Inquiry Model Based on Scientific Approach to Science Learning of the Students of Senior High School of 1 East Rote, East Nusa Tenggara The purpose of this study is to find out students' learning outcomes of cognitive, affective, using the application of the Guided Inquiry Model Based on the Scientific Approach

\section{RESEARCH METHODS}

The quantitative method was used in this study. The research sample consisted of two classes in SMA N 1 ROTE TIMUR, NTT, namely class XI MIA 1 and class XI MIA 2, who were drawn at random from a cluster. Class XI MIA 1 is an experimental class with 28 students in the learning process using a scientific-based guided inquiry model, while class XI MIA 2 has 30 students in the learning process using direct learning.

In order to collect data, researchers used cognitive tests with 15 questions in each subchapter, as well as an observation sheet. The validity and reliability of the question instrument were first determined using SPSS 16. After validation, the cognitive test instrument contained ten cognitive text questions per sub-chapter. Prerequisite test analysis and hypothesis analysis test have been used in the data analysis technique.

\section{RESULTS AND DISCUSSION}

The data in this research are cognitive and affective learning outcomes. Data obtained from the results of cognitive tests, questionnaires and observations. Class XI Natural Science 1 as the experimental class and XI Natural Science 2 as the control class. The results of research conducted at State Senior High School of 1 East Rote, East Nusa Tenggara obtained the following results.

Table 1. The Description of Cognitive Learning Outcomes Data

\begin{tabular}{lllll}
\hline Class & The number of students & Mean & Min & Max \\
\hline Experiment & 28 & 77.86 & 65 & 85 \\
Cognitive & 30 & 66.83 & 55 & 70 \\
\hline
\end{tabular}

From table 1, the significant aspect shows that the average score of the experimental class is higher than the control class.

Table 2. The Distribution of the Student Cognitive Aspects Score

\begin{tabular}{lcccc}
\hline Category & $\begin{array}{c}\text { Experiment } \\
\text { Respondents }\end{array}$ & $\begin{array}{c}\text { Percentage } \\
(\%)\end{array}$ & $\begin{array}{c}\text { Control } \\
\text { Respondents }\end{array}$ & $\begin{array}{c}\text { Percentage } \\
(\%)\end{array}$ \\
\hline Very well & 0 & 0 & 0 & 0 \\
Good & 24 & $80 \%$ & 7 & $25 \%$ \\
Moderate & 4 & $20 \%$ & 23 & $75 \%$ \\
Low & 0 & 0 & 0 & 0 \\
Very low & 0 & 0 & 0 & 0 \\
The number of student & 28 & 100 & 30 & 100 \\
\hline
\end{tabular}


In the cognitive aspect in table 2, in the control class there are $25 \%$ of students who are in good categories and $75 \%$ have moderate categories whereas in the experimental class there are $80 \%$ of students in good category and $20 \%$ of students in low category.

It is known that the learning outcomes in the knowledge aspect of the experimental class are higher than those in the control class. This is influenced by several elements of causal factors. In the experimental class that uses a guided inquiry learning model with a scientific approach is more fun and attracts students' interest in learning compared to direct learning that is usually used by teachers in the learning process, and related to students' involvement in the learning model is also needed. In the scientific-based guided inquiry learning model, it can facilitate students in finding the concept of reaction rate by observing the environment around the students themselves. This is supported by the statement (Ristanto 2010) which states that learning in a real environment can provide its own attractiveness for students in learning, where students can find something new that they can see and will make their own fun for students in learning.

Another supporting factor is the learning process that can be accommodated through the use of a learning model, a sanstific-based guided inquiry learning model. In selecting a model and learning approach that is good and appropriate, it can support learning styles, interest in learning which will make learning more meaningful and make students more interested in understanding what they are learning.

In the control class using the direct learning model while delivering learning material of reaction rate, teacher does not convey the actual or real learning object that can be seen by students. The method used has a major impact on the posttest learning outcomes carried out in the control class when learning is complete. Students in the control class have lower scores than students in the experimental class. This happens because the message conveyed by educators in learning is only through verbal words which results in the knowledge of each student will look more abstract. Which results in students understanding a learning rewarded with words without understanding and comparing themselves with what is happening in the world around them. In this learning method, not all students can quickly understand what is being taught. Only students with audio and visual learning style who can receive learning materials provided by teachers optimally. This results in lower learning activities in the control class when compared to the experimental class in which students will be directly involved in the learning process so that the atmosphere in the class is not stressful and is not teacher-centered. $\mathrm{n}$ contrast to the experimental class, the use of the Direct Instruction Model in the control class causes students' activities are limited only by listening to teachers' explanation, even though it is interspersed with discussion. However, the teacher still dominates learning so it does not involve the active role of the whole students (Hapsari 2011). In addition, the syntax in the Direct Instruction model of the control class does not train students' science process skills optimally (Wahyunningsih 2012), so that it has an impact on the limited role of students in the class.This can be seen in a glimpse of the scientific-based guided inquiry learning model from the aspect of orientation which is directed by students to focus on the material that will be conveyed. In this stage the teacher provides learning objectives so that students know learning activities and educators motivate and explore students' understanding of initial understanding in the learning process when interpreting the learning objectives to be described.

In the first syntax of orientation, At this stage, the teacher conveys the learning objectives so that students know the learning activities that will be carried out at that time, tries to explore students' initial understanding and motivates students. 
In the second syntax of exploration At this stage, the teacher provides an opportunity for students to make observations on the object of study through the activities of seeing, listening, and paying attention to the important things of the object (Nusyamsuddin, 2013)

The third syntax is formation. Activities to collect data are carried out by observing the school environment. This is in accordance with the provisions of the Minister of Education and Culture Regulation Number 81 A of 2013 which states that in the activity of collecting data, students can carry out experiments, observations, read other sources such as textbooks, observe objects or events, activities, and interviews with informants to obtain information (Wardani 2014)

The fourth syntax is the application, . Associating activities aim to build the ability to think and to be scientific. The data obtained is made a classification, processed, and found specific relationships. The results of associating activities allow students high-level critical thinking (higher order thinking skills) to think metacognitive (Arnellis. 2014)

The fifth syntax is validation.This activity is useful for developing the ability to think systematically, expressing opinions briefly and clearly, and developing good and correct language skills (Rochintaniawati 2014).

Table 3. The description the learning outcomes of students' affective aspects

\begin{tabular}{lcccc}
\hline Class & Number of Students & Mean & Min & Max \\
\hline Experiment & 28 & 78.05 & 62 & 89 \\
Control & 30 & 72.25 & 62 & 82 \\
\hline
\end{tabular}

From table 3, the affective aspect shows that the average score of the experimental class is higher than the control class.

Teaching using guided inquiry learning model based on a scientific approach, the learning outcomes of the experimental class critical thinking skill are higher in the effective aspect than the control class because the use of this learning model is more active conceptually, and involves students in the learning process where in the learning process students take part in learning activities according to the direction of the teacher. This is in accordance with the statement (Son 2014) which states that students must be continuously trained to solve problems based on facts that occur through a scientific approach. In the control class, it looks different with only using the direct learning method where students have the least opportunity to be actively involved in the learning process. In this learning more students are only given the opportunity to listen to and note things that are considered important that have been conveyed by the teacher without being able to understand concepts in their own language, so students are not allowed to seek and find meaning from everything they learn This is supported by the statement of (Putra 2014) which states that students must be trained to solve problems based on facts through a scientific approach. It is different from the control class that uses Direct Instruction learning, where students are given less opportunity to be actively involved in learning. The students only have a chance to hear and record important things conveyed by the teacher. Brunner in (Winataputra. 1993) states that students should be allowed to look for and find out the meaning from everything they learned so that the students are expected to be able to understand the concept by their own language.

Table 4. The hypothesis test results of cognitive and affective learning outcomes

\begin{tabular}{llc}
\hline Hypothesis & Learning Outcomes & P-value \\
\hline 1 & Cognitive & 0,000 \\
2 & Affective & 0.038 \\
\hline
\end{tabular}


In testing the hypothesis, the learning outcomes data used independent samples ttest for cognitive and affective aspects, testing used SPSS for Windows 16.0, and the significance level of the statistical test is carried out at the $5 \%$ level if the p-value $<0.05$ then Ho is rejected which means there is a difference, whereas if $p$-value $>0.05$ then Ho is accepted which means there is no difference. Testing the results of the hypothesis can be seen in table 4 below

In the hypothesis test, it can be seen that $\mathrm{HO}$ is rejected, which means the Scientificbased Guided Inquiry Model improves student learning outcomes in the cognitive aspects of the reaction rate material in State Senior High School of 1 Rote Timur, NTT in the 2019/2020 Academic Year. In table 4, it can be concluded that the cognitive and affective aspects of the student's hypothesis testing on the use of the scientific Guided Inquiry Model obtained the following conclusions.

\section{CONCLUSION}

The learning process using the Scientific-Based Guided Inquiry Model and the direct method shows that there is a significant difference in the average learning outcomes of high school students in cognitive and affective aspects. This is due to the use of learning model selection. In the guided inquiry learning model, it facilitates students to construct their own knowledge and is actively involved in learning so that student learning outcomes are better. The scientific-based guided inquiry model also enables students to recognize and apply the scientific method through detailed and cooperative steps. Thus, it can be concluded that the student's Chemical learning outcomes in the critical and affective thinking aspects are very different based on the application of the scientific-based guided inquiry learning model and the direct learning model.

\section{REFERENCES}

Anderson, LW, \& Krathwohl, DR (2011). A fundamental framework for learning, teaching, and assessment . (Prihantoro's Great Translation). Yogyakarta: Student Library. (Original edition published in 2001 by David McKay Company, Inc).

Arnellis, (2014). "The Scientific Approach in Mathematics Learning for Developing Mathematical Thinking Ability of Senior High School Students". National Seminar

Proceeding of Mathematics and Science (MIPA) Education 2014 "The Implementation of Scientific Approach in Mathematics and Science Education, Mathematics and Science Faculty, Padang State University".

Coffman, T. (2014). Engaging students through inquiry-oriented learning and technology. United States: Rowman \& Littlefield Education.

Conway, JC (2014). Effects of guided inquiry versus lecture instruction on final grade distribution in a one-semester organic and biochemistry course. Journal Of Chemistry Education, 91 (4), pp 480-483

Hapsari, Dewi Pertiwi, dkk. (2011). "The Influence of Guided Inquiry Model using V (Vee) Diagram on Critical Thinking Ability and Students' Learning Outcome for Biology Learning". Biology Education Journal 4(3) pp. 16-28.

Kuhlthau, CC, Maniotes, LK, and Caspari, AK (2007). Guided Inquiry Learning in the 21st century. London: Libraries Unlimited.

Machin, A. (2014). The Implementation of Scientific Approach, Character Building, and Conservation for Learning in the Material of Growth. Science Education Journal of Indonesia. JPII 3 (I) pp 28-35.

Ngalimun. (2017). Learning Strategies. Cross Karaya: PaRama Ilmu.

Nusyamsuddin, dkk. (2013). Competency-Based Learning with Scientific Approach. Jakarta: The Minister of Education and Culture of Indonesia. 
Oemar, H. "Teaching Planning Based on a Systems Approach". (Jakarta: Earth Literacy: 2001). p.188.

Son, Amali. (2014). "Observation-Based Science Learning with a Scientific Approach in Senior High Schools". Journal of Research Education, vol. 5, number. I, pp. 31-40

Putra, Amali. (2014). "Science Learning Based on Observation with Scientific Approach at

Senior High Schools". Research Education Journal, vol. 5, num.I, pp. 31-40

Ristanto, RH. (2010). Learning Based on Guided Inquiry Model with Multimedia and Real Environment in terms of Motivation and Initial Knowledge. Thesis. Sebelas Maret University Surakarta.

Rochintaniawati, Diana. (2014). "Science Learning with the Scientific Approach of Curriculum 2013", National Seminar Proceeding of Mathematics and Science Education in the Year of 2014 "The Implementation of Scientific Approach for Mathematics and Science Learning". Mathematics and Science Faculty. Padang State University.

Sanjaya, W. (2006). Learning Strategies. Jakarta: Kencana Prenada Media Group.

Sutresna, N. (2007). Intelligent learning chemistry for class XI SMA / MA natural science program . Bandung: Grafindo Media Pratama.

Uzuntiryaki , E., Boz, Y., \& Kirbulut, D. (2010). Do pre-service chemistry teachers reflect their beliefs about constructivism in their teaching practices?. Research in Science Education, 40 (3), pp 403-424.

Wahyunningsih, Sri., Baskoro Adi Prayitno, and Riezky Maya Probosa. (2012). The Influence of Guided Inquiry Model on Basic Science Ability Viewed from Students' Academic Skill at SMAN 5 Surakarta. Biology Education Journal Vol. 4

Wardani, Eva R.S, Johanes Djoko, and Sifak Indana. (2014). "The Analysis of Appropriateness of Learning Activiy Based on Scientific Approach with Learning

Objective at SMAN Mojokerto". BioEdu Journal. vol. 3, num. 3, p 601-605.

Winataputra. (1993). Learning Teaching Science Strategy. Jakarta: Indonesia Open University Universitas 